ISSN 1392-3196 / e-ISSN 2335-8947

Zemdirbyste-Agriculture, vol. 102, No. 4 (2015), p. 465-478

DOI 10.13080/z-a.2015.102.060

\title{
Bacterial endophytes in agricultural crops and their role in stress tolerance: a review
}

\author{
Inga MILIUTE ${ }^{1}$, Odeta BUZAITE ${ }^{1}$, Danas BANIULIS ${ }^{1}$, Vidmantas STANYS ${ }^{1,2}$ \\ ${ }^{1}$ Institute of Horticulture, Lithuanian Research Centre for Agriculture and Forestry \\ Kauno 30, Babtai, Kaunas distr., Lithuania \\ E-mail: v.stanys@1sdi.lt \\ ${ }^{2}$ Aleksandras Stulginskis University \\ Studentų 11, Akademija, Kaunas distr., Lithuania
}

\begin{abstract}
Bacterial endophytes are a class of endosymbiotic microorganisms widespread among plants that colonize intercellular and intracellular spaces of all plant compartments and do not cause plant disease or significant morphological changes. Plant and endophytic bacteria association includes vast diversity of bacterial taxa and plant hosts and in this review we present an overview of taxonomic composition of endophytes identified in common agricultural crops. Further, during the last decade, new aspects of the microbial diversity have emerged with application of new metagenomic analysis methods in studies of bacterial endophytes. Endophytic bacteria community structure is influenced by plant genotype, abiotic and biotic factors such as environment conditions, microbe - microbe interactions and plant - microbe interactions. Agricultural practices, such as soil tillage, irrigation, use of pesticides and fertilizers have a major effect on function and structure of soil and endophytic microbial populations. Therefore, the use of agricultural practices that maintain natural diversity of plant endophytic bacteria is becoming an important element of sustainable agriculture that could ensure plant productivity and quality of agricultural production. The diverse endophytic microbial communities play integral and unique role in the functioning of agroecosystems. Endophytic bacteria have been shown to have several beneficial effects on their host plant, including growth promoting activity, modulation of plant metabolism and phytohormone signalling that leads to adaptation to environmental abiotic or biotic stress. Use of endophytic bacteria presents a special interest for development of agricultural applications that ensure improved crop performance under cold, draught or contaminated soil stress conditions or enhanced disease resistance.
\end{abstract}

Key words: agricultural practices, endophytic microbiome, microbial community, microbial diversity, plant adaptation.

\section{Introduction}

Agricultural intensification in the $20^{\text {th }}$ century has been largely achieved through the use of farm equipment, high-yielding crop varieties, intensive tillage, irrigation, fertilizers, pesticides and other manufactured inputs (Foley et al., 2005). This is well illustrated by the global use of fertilizers that increased from approx. 27 to 170 million of nutrient tons over the past 50 years before 2010 (Bumb, Baanante, 1996; Heffer, 2013). However, detrimental effects of the agricultural practices on soil ecology, high irrigation needs, as well as effect on human health, have been recognized. Therefore new environmentally benign approaches have to be employed to maintain sustainable agricultural production and to overcome threats that lead to loss of crop yield, including plant stresses associated with unfavourable environmental conditions, such as drought, temperature extremes or soil salinity, as well as biotic stress induced by plant pathogens and pests. In this context, there is a strong case for using microorganisms for improved plant performance in integrated plant disease management systems (reviewed by Singh et al., 2011 and Jha et al., 2013). Microorganisms can provide beneficial effects on plants directly by enhancing crop nutrition or indirectly by reducing damage caused by pathogens or environmental stress.

Plants live in intimate association with microorganisms that fulfil important functions in agricultural ecosystems. Bacteria may exist as free-living organisms in soils or attached to the surface of roots or phylosphere, and may establish symbiotic relations with plants (Smith, Goodman, 1999). Endophytic bacteria are a class of endosymbiotic microorganisms that live in internal plant tissues of apparently healthy host plants (Schulz, Boyle, 2006). Unlike phytopathogens, such bacteria do not normally cause any substantial disease symptoms, and occurrence of endophytes is not associated with morphological changes of plant tissues such as caused by root-nodule symbionts. Endophytes 
colonize plant apoplast, including the intercellular spaces of the cell walls and xylem vessels of plant roots, stems and leaves, and they are also found in tissues or flowers (Compant et al., 2011), fruits (de Melo Pereira et al., 2012) and seeds (Trognitz et al., 2014). Population densities of endophyte bacteria are extremely variable in different plants and tissues and have been shown to vary from hundreds to reaching as high as $9 \times 10^{9}$ of bacteria per gram of plant tissue (Jacobs et al., 1985; Misaghi, Donndelinger, 1990; Chi et al., 2005). Typically, higher density of endophyte populations is found in plant roots and other below-ground tissues as compared to aboveground tissues, and ascending migration of endophytic bacteria from roots to leaves of rice plants has been demonstrated (Chi et al., 2005), suggesting roots as the main entry point of the potential endophytes from soil to the host plant. Although endophytic bacteria are adapted to living inside specific plant genotypes, a variety of reports indicate that structure of endophytic community is influenced by abiotic and biotic factors such as environment conditions, microbe - microbe interactions and plant - microbe interactions (Ryan et al., 2008).

It has been established that tight association between host-plant and endophytes is mediated through action of compounds produced by the microorganisms and the host cells (Reinhold-Hurek, Hurek, 2011; Brader et al., 2014). A large body of literature documented diverse effects of endophytic bacteria on plant health and growth. The endophytes aid nutrient availability and uptake, enhance stress tolerance, and provide disease resistance (Ryan et al., 2008; Hamilton et al., 2012). Plant growth promoting capability of endophytes could be directly established through production of plant growth hormones, interactions that alter endogenous plant hormone production or activity that increases accessibility of nutrients, such as nitrogen and phosphorus (Glick, 2012). Plant disease resistance promoting properties are associated with the ability of endophytic bacteria to produce a wide range of compounds, such as antibiotics or chitinase enzyme, which can inhibit growth of plant pathogens and thus act as biocontrol agents (Raaijmakers, Mazzola, 2012; Christina et al., 2013; Brader et al., 2014; Wang et al., 2014). Endophytes were also shown to stimulate a latent disease defense mechanism, termed as induced systemic resistance (ISR), that confers an enhanced level of protection to a broad spectrum of pathogens (Pieterse et al., 2014).

Owing to their plant growth promoting and disease control properties, endophytes can be used in the form of bioinoculants in agriculture as amendments to promote plant growth and health. A number of registered patents that are related to application of endophytic bacteria to enhance host tolerance to fungal pathogens as well as to promote plant growth demonstrate a potential for applications that would benefit development of sustainable agricultural production (Mei, Flinn, 2010).

Here, we provide an overview of the composition of bacterial populations that are found in endosphere of major crop plants grown in agricultural environment and recent advances in analysis approaches used in the endophytic microbiome research. Further, progress in understanding of complex interactions among the bacterial endophytes, effects of agricultural practices on endophytic bacterial communities and a role of the endophytes in plant adaptation to stress and disease resistance are considered.

\section{Occurrence and diversity of bacterial endophytes in agricultural crops}

Diverse endophytic bacteria play an integral role in ecosystems and plant physiology. These bacteria colonize all plant compartments, generally the intercellular and intracellular spaces of inner tissues. Initial studies on diversity of endophytic bacteria were mostly based on characterization of endophytic isolates obtained from the plant after surface disinfection. Lodewyckx et al. (2002) characterized the main methods used for the bacteria isolation and 81 bacterial species which form endophytic associations with plants. One of the early reviews by Hallman et al. (1997) presented a list of bacterial endophytes isolated from various plant parts of different agricultural crops. The list of endophytes and plants harbouring them was supplemented by later studies (Rosenblueth, Martinez-Romero, 2006; Bacon, Hinton, 2007; Ryan et al., 2008). A summary of most widespread bacterial isolates identified and common agricultural crop plants that serve as host for the bacteria are presented in Table. The list is incomplete as the endophytic bacteria and plant association include a vast diversity of bacterial taxa and plant hosts.

The early studies on composition of endophytic communities revealed that different plant hosts harbour similar community of bacterial endophytes (Mundt, Hinkle, 1976). The genera of Bacillus and Pseudomonas are identified as frequently occurring in agricultural crops (Seghers et al., 2004; Souza et al., 2013). Presence of different endophytic species depends mostly on plant and bacteria genotype, biotic and abiotic environmental factors. Meanwhile a single host plant species comprises several genera and species of endophytes, the tissue type of plant or season of isolation may determine extent of the endophytic population (Kuklinsky-Sobral et al., 2004; Rosenblueth, Martinez-Romero, 2006). A large study conducted on bacterial endopyte communities revealed that although endophytic bacteria colonize entire plant, the roots usually contain higher number of species. Endophytic species mostly belong to the $\alpha-, \beta$-, and $\gamma$-proteobacteria subgroups and are closely related to epiphytic species (Kuklinsky-Sobral et al., 2004). Interestingly, the $\gamma$-proteobacteria group is the most diverse and dominant. It has been reported that most of gram-negative endophytes act as agents of biological control (Kobayashi, Palumbo, 2000), while among the gram-positive bacteria the dominant endophytic species primarily those belonging to the Bacillus species are found (Gupta et al., 2002; Bacon, Hinton, 2007).

Most of the culturable isolated endophytic bacteria species belong to Proteobacteria, meanwhile Firmicutes, Actinobacteria and also Bacteroides are less 
Table. Endophytic bacteria isolated from common agricultural crop plants

\begin{tabular}{|c|c|c|}
\hline $\begin{array}{l}\text { Plant species } \\
\text { and organ }\end{array}$ & Bacterial endophyte taxa & References \\
\hline 1 & 2 & 3 \\
\hline $\begin{array}{l}\text { Alfalfa (Medicago } \\
\text { sativa L.) roots }\end{array}$ & $\begin{array}{l}\gamma \text {-proteobacteria: Erwinia sp., Pseudomonas sp. } \\
\text { firmicutes: Bacillus megaterium, } B \text {. chosinensis } \\
\text { actinobacteria: Microbacterium trichothecenolyticum }\end{array}$ & $\begin{array}{l}\text { Gagne et al., 1987; } \\
\text { Stajkovic et al., } 2009\end{array}$ \\
\hline $\begin{array}{l}\text { Black pepper (Piper } \\
\text { nigrum L.) roots }\end{array}$ & $\begin{array}{l}\gamma \text {-proteobacteria: Pseudomonas sp., Serratia sp. } \\
\text { firmicutes: Bacillus sp. } \\
\text { actinobacteria: Arthrobacter sp., Micrococcus sp., Curtobacterium sp. }\end{array}$ & Aravind et al., 2009 \\
\hline $\begin{array}{l}\text { Carrot (Daucus } \\
\text { carota L. var. sativus) }\end{array}$ & 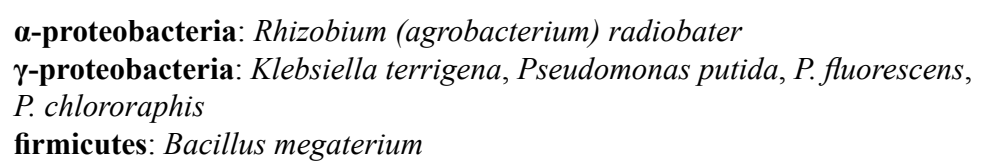 & Surette et al., 2003 \\
\hline Grape (Vitis spp.) stems & 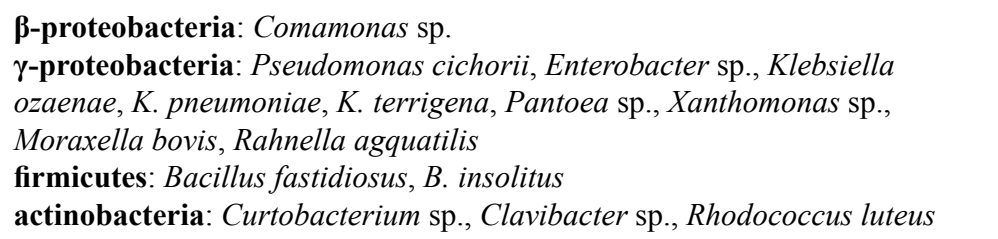 & $\begin{array}{l}\text { Bell et al., 1995; } \\
\text { West et al., } 2010\end{array}$ \\
\hline $\begin{array}{l}\text { Maize (Zea mays L.) } \\
\text { stems, roots }\end{array}$ & 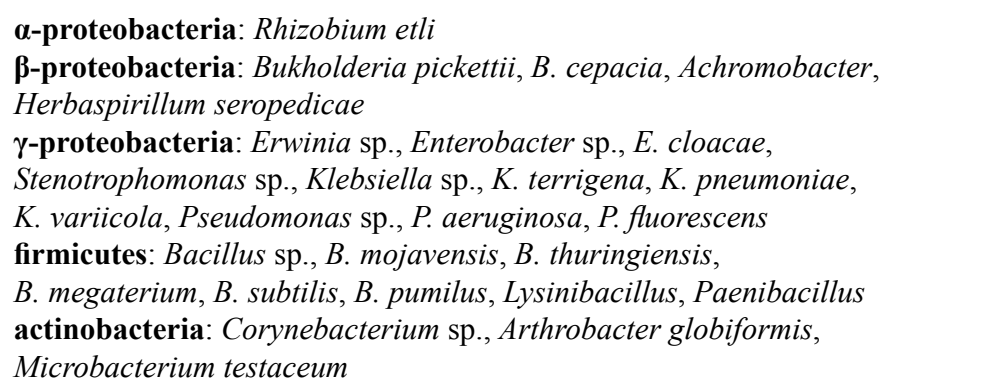 & $\begin{array}{l}\text { Lalande et al., 1989; } \\
\text { Fisher et al., 1992; } \\
\text { McInroy, Kloepper, } \\
\text { 1995; } \\
\text { Palus et al., 1996; } \\
\text { Chelius, Triplett, 2001; } \\
\text { Zinniel et al., 2002; } \\
\text { Rosenblueth, Martinez- } \\
\text { Romero, 2004; } \\
\text { Rai et al., } 2007\end{array}$ \\
\hline $\begin{array}{l}\text { Potato (Solanum } \\
\text { tuberosum L., Ipomoea } \\
\text { batatas) tubers and } \\
\text { stems }\end{array}$ & 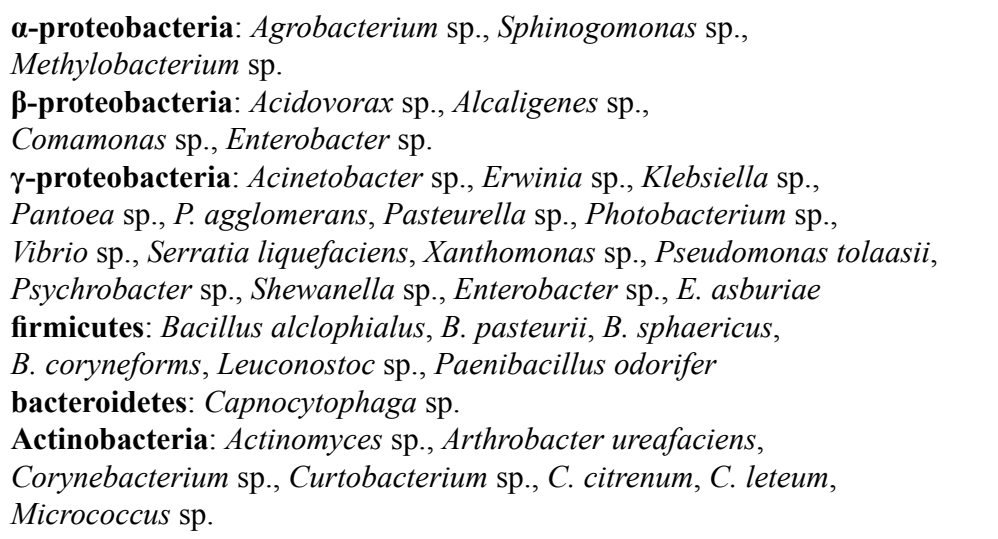 & $\begin{array}{l}\text { Hollis, 1951; } \\
\text { De Boer, Copeman, } \\
\text { 1974; Sturz et al., 2000; } \\
\text { Reiter et al., 2002; } \\
\text { Sturz et al., } 1998\end{array}$ \\
\hline $\begin{array}{l}\text { Radish (Raphanus } \\
\text { sativus L.) leaves and } \\
\text { roots }\end{array}$ & proteobacteria: Proteobacteria sp. & Seo et al., 2010 \\
\hline $\begin{array}{l}\text { Red clover (Trifolium } \\
\text { Pratense L.), leaves, } \\
\text { stems, roots and fresh } \\
\text { nodules }\end{array}$ & 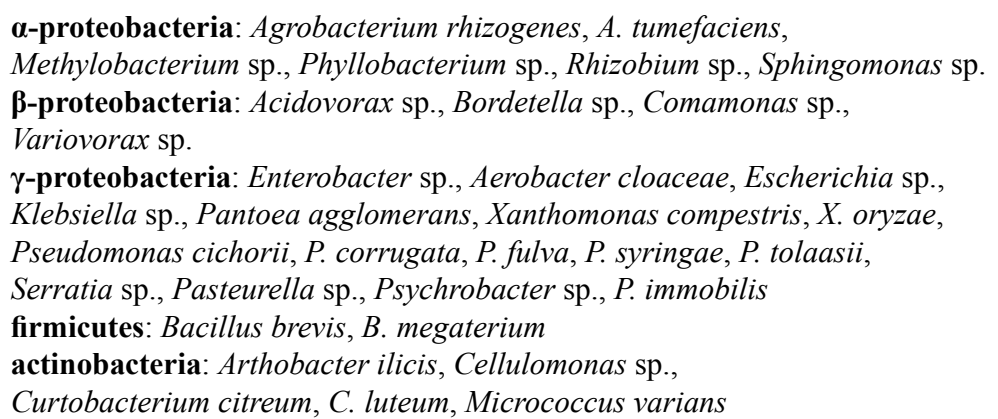 & Sturz et al., 1998 \\
\hline
\end{tabular}




\section{Table continued}

\begin{tabular}{|c|c|c|}
\hline 1 & 2 & 3 \\
\hline $\begin{array}{l}\text { Wild rice (Oryza } \\
\text { officinalis, O. barthii, } \\
\text { O. rufipogon, } \\
\text { O. glandiglumis, } \\
\text { O. breviligulata }) \text { and } \\
\text { cultivated rice } \\
(O . \text { sativa } \text { L.) roots and } \\
\text { stems }\end{array}$ & 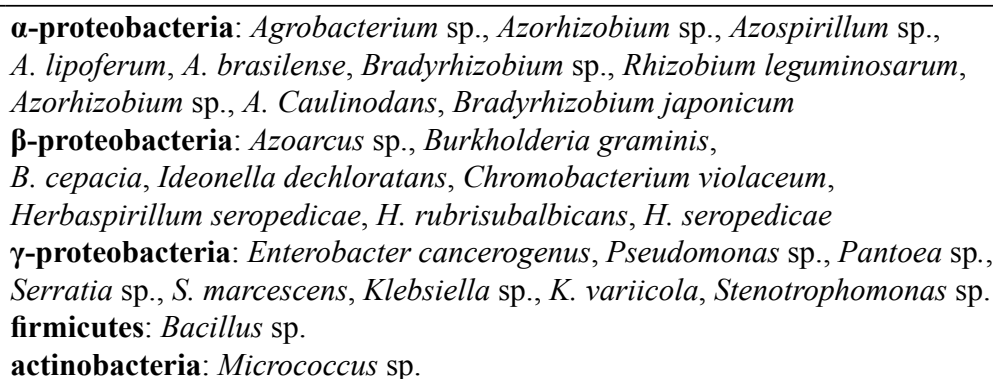 & $\begin{array}{l}\text { You, Zhou, 1989; } \\
\text { Stolzfus et al., 1997; } \\
\text { Yanni et al., 1997; } \\
\text { Chaintreuil et al., 2000; } \\
\text { Engelhard et al., 2000; } \\
\text { Elbeltagy et al., 2001; } \\
\text { Sandhiya et al., 2005; } \\
\text { Mbai et al., 2015 }\end{array}$ \\
\hline
\end{tabular}

Sugar beet (Beta vulgaris $\mathrm{L}$.) roots

Soybean (Glycine $\max ($ L.) Merr.) stems, leaves, roots and nodules

Tomato (Lycopersicon Esculentum Mill.) stems and fruits

Wheat (Triticum aestivum $\mathrm{L}$.) roots

\author{
$\gamma$-proteobacteria: Erwinia sp., Pseudomonas sp., Xanthomonas sp. \\ firmicutes: Bacillus sp., Lactobacillus sp. \\ actinobacteria: Corynebacterium sp.
}

a-proteobacteria: Erwinia sp., Agrobacterium sp.

$\gamma$-proteobacteria: Pseudomonas citronellolis, P. oryzihabitans, P. staminea, K. pneumoniae, K. oxytoca, Enterobacter sp., Pantoea sp., P. agglomerans firmicutes: Bacillus fastidiosus

$\gamma$-proteobacteria: Pseudomonas sp., P. syringae, P. aeruginosa, Escherichia coli

firmicutes: Brevibacillus brevis
Jacobs et al., 1985;

Dent et al., 2004

Zinniel et al., 2002; Kuklinsky-Sobral et al., 2004

Samish et al., 1961; Pillay, Nowak, 1997; Yang et al., 2011; Patel et al., 2012

Mavingui et al., 1992; Balandreau et al., 2001; Zinniel et al., 2002; Iniguez et al., 2004 common (Reinhold-Hurek, Hurek, 2011). This suggests that part of communities of bacterial endophytes could be overlooked and others are overrepresented based on their capability to grow on synthetic medium. To draw a more precise picture of the diversity of endophytic microorganisms, recently a number of studies have been focused on identification of unculturable endophytes using novel metagenomic analysis approaches. Direct amplification of microbial DNA from plant tissue samples and application of modern bioinformatics tools allow analysis of a bacterial community composition and its phylogenetic structure inside a variety of plant organs or tissues (Chun et al., 2007; Manter et al., 2010). Sessitsch et al. (2012) analyzed genomic characteristics of bacterial endophytes colonizing rice roots under field conditions. These authors found that the population was dominated by members of $\gamma$-proteobacteria, comprising mostly enterobacter-related endophytes. However, application of culture independent methods allowed studies of growing numbers of plant material samples and revealed rarely reported endophyte species of $\delta$ - and $\varepsilon$-proteobacteria in rice roots (Sun et al., 2008). Tsurumaru et al. (2015) analyzed a metagenome of the bacterial community associated with the taproot of sugar beet (Beta vulgari L.) The study found that Alphaproteobacteria are dominant, followed by the Actinobacteria and the Betaproteobacteria. Another metagenomic study of the sorghum root and stem microbiome revealed that the two tissues harboured significantly different composition of bacterial communities, but both were dominated by agriculturally important genera such as Microbacterium,
Agrobacterium, Sphingobacterium, Herbaspirillum, Erwinia, Pseudomonas and Stenotrophomonas (Maropola et al., 2015).

Metagenomic analysis involves direct isolation of bacterial DNA, library construction and functional analysis (Handelsman, 2004; Jiao et al., 2006). To investigate endophytic bacterial diversity, highly specific methods should be used (Sun et al., 2008). Initial studies on the unculturable bacterial endophyte diversity revealed technical limitation related to separation of endophytic bacteria from plant nuclei, plastids, mitochondria and plant associated microbial DNA (Govindasamy et al., 2014). As plant DNA is much more abundant than bacterial, it is difficult to isolate and sequence only bacterial community at high coverage. In order to avoid plant host DNA, enrichment of endophytic bacteria prior to DNA amplification should be done (Govindasamy et al., 2014). To exclude interference of plant host DNA, Jiao et al. (2006) enriched bacterial endophytes by hydrolysis of the plant cell walls, followed by differential centrifugation. For bacterial DNA ratio enrichment in stems and leaves of soybean and rice, Ikeda et al. (2009) used series of differential centrifugation steps followed by density gradient centrifugation. Another technique suitable for extraction of endophytes from internal tissues of potato tubers was developed by Nikolic et al. (2011) and involved overnight shaking of the small pieces of potato tubers in sodium chloride solution. Although the method allowed bacterial DNA extraction from a large amount of plant material, diversity of rare members of endophytic metagenome could be also reduced. 


\section{Interactions within the population of bacterial endophytes}

Endophytic bacteria are known to produce a wide variety of secondary metabolites and hydrolytic enzymes. Discovery of novel endophytic metabolites and investigation of their involvement in plant metabolism is an active field of research (recently reviewed by Brader et al., 2014). A large number of the compounds produced by endophytes possess antibacterial or antifungal activity. So far, the main research on antimicrobial activity of endophytes has been mainly focused on impact of endophytes on pathogenic bacteria and fungi. However, an abundance of endophytic bacteria and potential of metabolic signalling suggests presence of the multidimensional network of competing and symbiotic interactions in plant endosphere, which is difficult to model in in vitro experiments. Therefore elucidation of the molecular basis for interactions among the endophytic bacteria and their effect on endophytic fungi largely remains a challenge for future research.

The fact that many endophytic bacteria contain quorum sensing systems suggests a complex interaction between the bacteria in endosphere. Quorum sensing signals are involved in plant colonization by Methylobacterium (Dourado et al., 2014). Metagenomic analysis revealed that three quorum sensing systems autoinducer-2 system, the diffusible signal factor system and $\mathrm{N}$-acyl homoserine lactone (AHL) system are present in endophytic rice microbiome (Sessitsch et al., 2012). The AHL signalling is prevalent in Populus deltoides endophytic microbiome (Schaefer et al., 2013). The example of interactions between species based on quorum sensing was revealed in a study on plant pathogen causing olive (Olea europaea L.) knot disease Pseudomonas savastanoi pv. Savastanoi, and enterobacteria Pantoea agglomerans and Erwinia toletana. All three bacteria produced AHLs and shared one AHL quorum sensing system. $P$. savastanoi AHL quorum sensing mutants had impaired virulence. E. toletana knot formation ability by pathogen was regained when olive was co-inoculated with P. savastanoi AHL synthase mutant (Hosni et al., 2011). It was demonstrated that plants actively participate in AHL signalling as presence of the AHLs altered expression of number of plant genes including those involved in plant defense responses and plants were shown to mimic bacterial AHLs (reviewed by Hartmann et al., 2014).

Quorum sensing signals can be "intercepted" by signal degrading molecules - the effect known as quorum quenching. Endophytic Bacillus isolates from Cannabis sativa quenched four different AHLs used by Chromobacterium violaceum in violacein production regulation (Kusari et al., 2014). Extracts of endophyte bacteria Bacillus and Enterobacter from Pterocarpus showed AHLs degrading ability when applied on biosensor strains (Rajesh, Ravishankar, 2014). N-acylL-homoserine lactone acylase with specificity against medium and long chain AHLs was found in endophytic Streptomyces (Chankhamhaengdecha et al., 2013). AHL lactonase gene from Bacillus thuringiensis was introduced into endophytic Burkholderia which then was able to attenuate symptoms caused by pathogenic Burkholderia glumae in rice and Erwinia carotovora in potatoes (Cho et al., 2007).

Recent studies have revealed that bacterial endophytes are involved in complex interactions with endophytic fungi. For example, Burkholderia rhizoxinica endosymbiont of endophytic fungus Rhizopus microsporus controls vegetative reproduction of the host fungus (Lackner et al., 2011). Endophytic bacteria identified as Luteibacter enhances indole-3-acetic acid (IAA) production in vitro by endophyte Pestaliotopsis, meanwhile bacteria alone fail to produce IAA on medium and endophytic fungi produce significantly smaller amounts of IAA in absence of the bacterium (Hoffman et al., 2013).

\section{Effect of agricultural practices on endophytic bacterial communities}

Agricultural land management greatly alters soil characteristics, including physical, chemical and biological properties (Jangid et al., 2008; Garcia-Orenes et al., 2013). Soil tillage may lead to reduction in soil microbial diversity due to mechanical destruction, soil compaction, reduced pore volume, desiccation and disruption of access to food resources. Excessive use of pesticides can induce significant changes in the function and structure of soil microbial populations (Pampulha, Oliveira, 2006). The effect of pesticides may manifest a direct inhibitory effect on microbial growth and metabolism, as well as microbial diversity may change due to overall changes in the structure of agricultural ecosystems. Agricultural management alters the quantity and quality of plant residues entering the soil and their spatial distribution, through changes in nutrients and inputs (Christensen, 1996). Likewise, application of mineral or organic fertilizers has a different effect on composition of microbial community and microbial biomass (Zhong et al., 2010). Microbial diversity and metabolic activity is significantly increased by application of organic manure. However, the application of manures introduces faecal bacteria into soil and has the potential to alter the composition of the endogenous microbial population and to pose environmental hazards (Soupir et al., 2006).

The majority of bacteria in plant endosphere are presumed to have a "facultative endophyte" lifestyle and a stage in their life cycle in which they exist outside the host plants (Hardoim et al., 2008). These endophytes often originate from soil, initially infecting roots of the host plant and colonizing the plant apoplast. Therefore it could be presumed that the endophytic community represents a certain subset of the wider microbial population of rhizosphere and it would reflect differences induced by agronomic practices that are characteristic of soil microbial community. However, research on the effect of agricultural practices on endophyte population dynamics is limited to several studies.

It was demonstrated that colonization ability of nitrogen-fixing endophytic bacterium Acetobacter diazotrophicus is largely decreased in the sugarcane plants 
fertilized with high levels of nitrogen (Fuentes-Ramirez et al., 1999). Analysis of the endophytic population of maize roots under treatment with herbicides and different fertilizer types revealed that microbial group-specific genetic pattern differentiated the maize plants, cultivated by using mineral fertilizer, from the plants cultivated by using organic fertilizer (Seghers et al., 2004). Meanwhile, no significant effect of herbicide treatment on composition of the root endophyte population was detected. These studies did not reveal if the changes in endophyte population were a consequence of changes in overall soil microbial population upon the fertilizer treatment or the agronomic practices had a direct effect on the root endophytic community. However, another study, demonstrating that application of chitin resulted in changes in bacterial communities in soil, rhizosphere and cotton roots, suggested that the organic amendment supported endophytic species in cotton roots that otherwise did not occur (Hallman et al., 1999). Intriguingly, it was shown that the composition of the endophytic community was largely different from that of the rhizosphere, suggesting that the composition of the endophytic population was not directly determined by microbial diversity of the rhizosphere, but involved other factors related to plant biochemistry. Therefore the amendment of chitin, that enhanced chitinase and peroxidase concentrations, might have changed a preference of the plants for certain bacterial endophytes.

The importance of agricultural practices that maintain natural diversity of plant endophytic bacteria is emphasized by the observations that agricultural plants may become a niche for human pathogens and a source for outbreaks of food-borne illness (Brandl, 2006). Pathogenic bacteria of the family Enterobacteriaceae including pathogenic Salmonella genus strains, Escherichia coli and Vibrio cholerae strains, and the human opportunistic pathogen Pseudomonas aeruginosa were described as endophytic colonizers of plants (Kutter et al., 2006; Schikora et al., 2008; Deering et al., 2012; Akhtyamova, 2013). The colonization of plants by the human pathogens may be associated with the use of manures contaminated with faecal bacteria (Brandl, 2006; Holden et al., 2009), as well as the use of practices that lead to decline in soil and endophytic microbial populations and a reduced number and abundance of species antagonistic to the human pathogens (Latz et al., 2012).

Another aspect related to the effect of agricultural practices on soil and plant microbiome is reflected by the disease-suppressive soil phenomenon defined as "soils in which plants do not suffer from certain diseases or where disease severity is substantially reduced even though a virulent pathogen is present and the host plant is susceptible to the disease" (Weller et al., 2002; Haas, Defago, 2005). Biological suppression of soilborne diseases is a function of activity and composition of soil microbiome. It was shown several decades ago that disease suppressive properties of soil were largely induced by long-term cultivation of wheat and potato monoculture leading to build up of host specific microbial community (Scher, Baker, 1980; Whipps, 1997; Lorang et al., 1989). Further studies elucidated possible mechanisms of disease suppression that include competition for space and nutrients, antagonism due to production of secondary metabolites and elicitation of induced systemic resistance (ISR) (Philippot et al., 2013; Pieterse et al., 2014). Specific role of the endophytic bacteria in development of the disease suppressive traits was rarely addressed in the studies on disease suppressive soil communities; however, bacteria of genus Streptomyces, Bacillus, Actinomyces, Pseudomonas that lead endophytic lifestyle were shown to contribute to the disease suppressive traits of soils (Siddiqui, EhteshamulHaque, 2001; Weller et al., 2002; Haas, Defago, 2005; Mendes et al., 2011; Kinkel et al., 2012).

\section{Role of endophytes in adaptation of agricultural crops to biotic and abiotic environmental stress}

Endophytic bacteria have been shown to have several beneficial effects on their host plant. Plant growth is promoted through improved nutrient acquisition, including nitrogen fixation (Mirza et al., 2001) and production of plant growth enhancing substances such as cytokinins (Garcia de Salamone et al., 2001) and indole acetic acid (IAA) (Naveed et al., 2015). In addition to enhanced growth properties, modulation of plant metabolism and phytohormone signalling by the endophytic bacteria enhances adaptation to environmental abiotic or biotic stress. Endophytic bacteria present a special interest for improved crop adaptation to stress as they have the advantage of being relatively protected from the harsh environment of the soil under draught, high salt or other stress conditions (Sturz et al., 2000).

It was shown that bacterial endophyte Burkholderia phytofirmans PsJN enhances cold tolerance of grapevine plants by altering photosynthetic activity and metabolism of carbohydrates involved in cold stress tolerance (Ait et al., 2006; Fernandez et al., 2012). The bacterium presence in the plant promoted acclimation to chilling temperatures resulting in lower cell damage, higher photosynthetic activity, and accumulation of cold-stress-related metabolites such as starch, proline, and phenolic compounds. Similar positive effect of the bacterium on metabolic balance and reduced effect of drought stress was demonstrated in wheat plants grown under reduced irrigation conditions (Naveed et al., 2014). Endophytic bacteria Pseudomonas pseudoalcaligenes was shown to induce accumulation of higher concentrations of glycine betain-like compounds leading to improved salinity stress tolerance in rice (Jha et al., 2011).

Cohen et al. (2009) demonstrated that water stress tolerance in maize plants was alleviated by accumulation of the abscisic acid (ABA) produced by endophytic Azospirillum spp. and the effect was further enhanced by plant growth promoting hormones IAA and gibberellins. ABA is the phytohormone critical for plant growth and development and its levels are known to rise under stress condition. Main function of ABA seems to be the regulation of plant water balance and osmotic stress tolerance (Tuteja, 2007). 
Ethylene is another important plant hormone that is the extensively studied mediator of plant stress response signalling. Ethylene is formed from methionine via S-adenosyl-Lmethionine, which is converted into 1-aminocyclopropane-1-carboxylic acid (ACC) by the enzyme ACC oxidase (Bleecker, Kende, 2000). Stress induced accumulation of ethylene is usually deleterious to plant growth and health (Czarny et al., 2006). Endophytes may produce the enzyme ACC deaminase that has no function in bacteria but contributes to plant growth promotion and improved stress tolerance by cleaving the ethylene precursor ACC (Campbell, Thompson, 1996; Glick, 2014). There are numerous reports on ACC deaminase-containing plant-associated bacteria and their role in improved plant growth and stress tolerance that was recently reviewed by Glick (2014). The effect of endophytic bacteria-derived ACC deaminase activity on salt stress was most studied. Endophytic diazotrophic Achromobacter xylosoxidans AUM54 isolated from Catharanthus roseus grown in saline soil showed ability to produce ACC deaminase and to reduce ethylene levels (Karthikeyan et al., 2012). Improved plant growth in $150 \mathrm{mM} \mathrm{NaCl}$ containing soils was demonstrated for the plants inoculated with the A. xylosoxidans AUM54 strain. Recently, the study by Qin et al. (2014) revealed that halophyte plant Limonium sinense was naturally associated with ACC deaminase producing putative endophytic bacteria that might play important role in higher salinity tolerance of the plant. Thirteen isolates possessing ACC deaminase activity were obtained that belonged to genera: Bacillus, Pseudomonas, Klebsiella, Serratia, Arthrobacter, Streptomyces, Isoptericola and Microbacterium. Four of the selected ACC deaminaseproducing strains were shown to stimulate growth of the host plants. In another study, tomato plants grown under $165 \mathrm{mM}$ and $185 \mathrm{mM} \mathrm{NaCl}$ levels exhibited higher gain of biomass and a greater number of flowers and buds when pretreated with ACC deaminase containing bacterial endophytes Pseudomonas fluorescens YsS6 and P. migulae 8R6 as compared to treatment with ACC deaminase deficient mutants of the bacteria (Ali et al., 2014). The study revealed that endophytic bacteria affected plants differently under salt stress conditions as compared to other rhizospheric bacteria, such as Pseudomonas putida UW4 that was studied by Cheng et al. (2007). Meanwhile the reduced ethylene levels due to ACC deaminase activity were observed in both cases, the later study showed that the rhizospheric bacteria allowed the salt to accumulate in root tissues and presumably partition into the vacuole (Cheng et al., 2007), while the bacterial endophytes limited the concentration of sodium in plant shoots (Ali et al., 2014).

In addition, ACC deaminase producing Pantoea agglomerans Jp3-3 and Achromobacter xylosoxidans strain Ax 10 were shown to alleviate stress of Brassica sp. plants grown in copper-contaminated soils and improved copper uptake by the plants (Ma et al., 2009; Zhang et al., 2011 a). ACC deaminase producing isolates from Commelina communis plants grown on lead and zinc mine soils were shown to improve growth of rape plants in the lead-contaminated soil (Zhang et al., 2011 b).

The study on cold resistance of vine plants inoculated by Burkholderia phytofirmans PsJN revealed that the colonization of endophytic bacteria placed metabolism of the grapevine in the primed state that enabled higher and faster accumulation of stress related gene transcripts and metabolites leading to more effective resistance to cold stress (Theocharis et al., 2012). This provided insight into the priming phenomenon implicated in stress tolerance induced by plant-associated bacteria. However, so far the role of the priming in resistance to abiotic stress has attracted less attention as compared to the pathogen defense response priming that is proven to be a critical process of the induced systemic resistance (ISR) activated by non-pathogenic plant-associated microorganisms. The protection of cucumber plants against cucumber anthracnose induced by Pseudomonas fluorescens strain 89B-61 was the first case demonstrating that endophytic bacteria could elicit ISR in plants and published in 1991 (Wei et al., 1991; Kloepper, Ryu, 2006). Subsequent studies established that the ISR was induced by endophytic bacteria of genus Bacillus, Pseudomonas and Serratia in different plant-pathogen systems and molecular cell signalling mechanisms involved in the defense priming were previously reviewed (Kloepper, Ryu, 2006; Pieterse et al., 2014).

The ISR primes plant defense mechanisms and protects non-exposed plant parts against a future attack by pathogenic microbes and herbivorous insects. Although several plant-associated bacteria have been reported to induce a salicylic acid mediated type of induced systemic resistance, the plant hormones jasmonic acid (JA) and ethylene (ET) play a major regulatory role in the network of interconnected signalling pathways involved in ISR induction (Pieterse et al., 2012). Meanwhile the detailed mechanism of the defense priming during ISR remains elusive, the evidence for role of transcription co-regulator NPR1 in the JA/ET-dependent ISR has been provided and the cytosol specific function of the NPR1, different from the function involved in pathogen induced systemic acquired resistance, has been revealed (Spoel et al., 2003; Stein et al., 2008). Further, the role of transcription factors MYB72 and MYC2 in establishment of the ISR induced by rhizobacteria and priming of JA/ET-dependent defense genes has been demonstrated (Pozo et al., 2008; Van Der Ent et al., 2008).

\section{Conclusion and outlook}

A vast diversity of endophytic bacteria isolated from a large number of agricultural plants suggests that the bacteria play an integral role in balancing plant physiology and functioning of agroecosystems. Composition of the endosphere microbial populations depends mostly on plant and bacteria genotype, biotic and abiotic environmental factors. Endophytic species have been mostly reported throughout the $\alpha-, \beta-$, and $\gamma$-proteobacteria subgroups and the latter is the most diverse and dominant group. The genera of Bacillus and Pseudomonas are identified as frequently occurring in agricultural crops. During the last decade development of metagenomic analysis techniques has brought to light new information on the diversity of unculturable endophytic bacteria and provided important prospects for understanding complex interactions within the microbial 
community and with the plant host. Numerous studies demonstrate beneficial effects of the endophytic bacteria on plant growth and adaptability to biotic or abiotic stresses. Therefore understanding of composition and functioning of plant associated microbial communities as well as control of the structure of endophytic bacterial populations through development of environmentally benign agricultural practices has a large potential for improved plant performance and application of the integrated plant disease management systems required for sustainable agricultural production.

\section{Acknowledgments}

This work was funded by the Lithuanian Research Council, grant No. MIP-47/2013.

Received 04062015

Accepted 18092015

\section{References}

Ait B. E., Nowak J., Clement C. 2006. Enhancement of chilling resistance of inoculated grapevine plantlets with a plant growth-promoting rhizobacterium, Burkholderia phytofirmans strain PsJN. Applied and Environmental Microbiology, 72 (11): 7246-7252

http://dx.doi.org/10.1128/AEM.01047-06

Akhtyamova N. 2013. Human pathogens-the plant and useful endophytes. Journal of Medical Microbiology and Diagnosis, 2: e121

http://dx.doi.org/10.4172/2161-0703.1000e121

Ali S., Charles T. C., Glick B. R. 2014. Amelioration of high salinity stress damage by plant growth-promoting bacterial endophytes that contain ACC deaminase. Plant Physiology and Biochemistry, 80: 160-167 http://dx.doi.org/10.1016/j.plaphy.2014.04.003

Aravind R., Kumar A., Eapen S. J., Ramana K. V. 2009. Endophytic bacterial flora in root and stem tissues of black pepper (Piper nigrum L.) genotype: isolation, identification and evaluation against Phytophthora capsici. Letters in Applied Microbiology, 48 (1): 58-64 http://dx.doi.org/10.1111/j.1472-765X.2008.02486.x

Bacon C. W., Hinton D. M. 2007. Bacterial endophytes: the endophytic niche, its occupants, and its utility. Plantassociated bacteria, p. 155-194

Balandreau J., Viallard V., Cournoyer B., Coenye T., Laevens S., Vandamme P. 2001. Burkholderia cepacia genomovar III is a common plant-associated bacterium. Applied and Environmental Microbiology, 67 (2): 982-985 http://dx.doi.org/10.1128/AEM.67.2.982-985.2001

Bell C. R., Dickie G. A., Harvey W. L. G., Chan J. W. Y. F. 1995. Endophytic bacteria in grapevine. Canadian Journal of Microbiology, 41: 46-53 http://dx.doi.org/10.1139/m95-006

Bleecker A. B., Kende H. 2000. Ethylene: a gaseous signal molecule in plants. Annual Review of Cell and Developmental Biology, 16: 1-18 http://dx.doi.org/10.1146/annurev.cellbio.16.1.1

Brader G., Compant S., Mitter B., Trognitz F., Sessitsch A. 2014. Metabolic potential of endophytic bacteria. Current Opinion in Biotechnology, 27: 30-37 http://dx.doi.org/10.1016/j.copbio.2013.09.012

Brandl M. T. 2006. Fitness of human enteric pathogens on plants and implications for food safety. Annual Review of Phytopathology, 44: 367-392

http://dx.doi.org/10.1146/annurev.phyto.44.070505.143359
Bumb B. L., Baanante C. A. 1996. World trends in fertilizer use and projections to 2020. International Food Policy Research Institute, p. 1-4

Campbell B. G., Thompson J. A. 1996. 1-Aminocyclopropane1-carboxylate deaminase genes from Pseudomonas strains. FEMS Microbiology Letters, 138: 207-210 http://dx.doi.org/10.1111/j.1574-6968.1996.tb08158.x

Chaintreuil C., Giraud E., Prin Y., Lorquin J., Ba A., Gillis M., de Lajudie P., Dreyfus B. 2000. Photosynthetic bradyrhizobia are natural endophytes of the African wild rice Oryza breviligulata. Applied and Environmental Microbiology, 66 (12): 5437-5447 http://dx.doi.org/10.1128/AEM.66.12.5437-5447.2000

Chankhamhaengdecha S., Hongvijit S., Srichaisupakit A., Charnchai P., Panbangred W. 2013. Endophytic actinomycetes: a novel source of potential acyl homoserine lactone degrading enzymes. BioMed Research International, 2013: 782-847 http://dx.doi.org/10.1155/2013/782847

Chelius M. K., Triplett E. W. 2001. The diversity of archaea and bacteria in association with the roots of Zea mays $\mathrm{L}$. Microbial Ecology, 41 (3): 252-263 http://dx.doi.org/10.1007/s002480000087

Cheng Z., Park E., Glick B. R. 2007. 1-Aminocyclopropane1-carboxylate deaminase from Pseudomonas putida UW4 facilitates the growth of canola in the presence of salt. Canadian Journal of Microbiology, 53 (7): 912-918 http://dx.doi.org/10.1139/W07-050

Chi F., Shen S. H., Cheng H. P., Jing Y. X., Yanni Y. G., Dazzo F. B. 2005. Ascending migration of endophytic rhizobia, from roots to leaves, inside rice plants and assessment of benefits to rice growth physiology. Applied and Environmental Microbiology, 71 (11): 7271-7278 http://dx.doi.org/10.1128/AEM.71.11.7271-7278.2005

Cho H. S., Park S. Y., Ryu C. M., Kim J. F., Kim J. G., Park S. H. 2007. Interference of quorum sensing and virulence of the rice pathogen Burkholderia glumae by an engineered endophytic bacterium. FEMS Microbiology Ecology, 60 (1): 14-23 http://dx.doi.org/10.1111/j.1574-6941.2007.00280.x

Christensen B. T. 1996. Matching measurable soil organic matter fractions with conceptual pools in simulation models of carbon turnover: revision of model structure. Evaluation of soil organic matter models using existing long-term datasets. Global environmental change, p. 143-160

Christina A., Christapher V., Bhore S. J. 2013. Endophytic bacteria as a source of novel antibiotics: an overview. Pharmacognosy Reviews, 7 (13): 11-16

Chun J., Lee J. H., Jung Y., Kim M., Kim S., Kim B. K., Lim Y.W. 2007. EzTaxon: a web-based tool for the identification of prokaryotes based on $16 \mathrm{~S}$ ribosomal RNA gene sequences. International Journal of Systematic and Evolutionary Microbiology, 57 (Pt 10): 2259-2261 http://dx.doi.org/10.1099/ijs.0.64915-0

Cohen A. C., Travaglia C. N., Bottini R., Piccoli P. N. 2009. Participation of abscisic acid and gibberellins produced by endophytic Azospirillum in the alleviation of drought effects in maize. Botany, 87 (5): 455-462 http://dx.doi.org/10.1139/B09-023

Compant S., Mitter B., Colli-Mull J. G., Gangl H., Sessitsch A. 2011. Endophytes of grapevine flowers, berries, and seeds: identification of cultivable bacteria, comparison with other plant parts, and visualization of niches of colonization. Microbial Ecology, 62 (1): 188-197 http://dx.doi.org/10.1007/s00248-011-9883-y

Czarny J. C., Grichko V. P., Glick B. R. 2006. Genetic modulation of ethylene biosynthesis and signaling in plants. Biotechnology Advances, 24 (4): 410-419 http://dx.doi.org/10.1016/j.biotechadv.2006.01.003 
De Boer S. H., Copeman R. J. 1974. Endophytic bacterial flora in Solanum tuberosum and its significance in bacterial ring rot disease. Canadian Journal of Plant Science, 54: $115-122$ http://dx.doi.org/10.4141/cjps74-019

de Melo Pereira G. V., Magalhaes K. T., Lorenzetii E. R., Souza T. P., Schwan R. F. 2012. A multiphasic approach for the identification of endophytic bacterial in strawberry fruit and their potential for plant growth promotion. Microbial Ecology, 63 (2): 405-417 http://dx.doi.org/10.1007/s00248-011-9919-3

Deering A. J., Mauer L. J., Pruitt R. E. 2012. Internalization of E. coli $\mathrm{O} 157: \mathrm{H} 7$ and Salmonella spp. in plants: a review. Food Research International, 45: 567-575 http://dx.doi.org/10.1016/j.foodres.2011.06.058

Dent K. C., Stephen J. R., Finch-Savage W. E. 2004. Molecular profiling of microbial communities associated with seeds of Beta vulgaris subsp. vulgaris (sugar beet). Journal of Microbiological Methods, 56 (1): 17-26 http://dx.doi.org/10.1016/j.mimet.2003.09.001

Dourado M. N., Bogas A. C., Pomini A. M., Andreote F. D., Quecine C., Marsaioli A. J., Araujo W. L. 2014. Methylobacterium-plant interaction genes regulated by plant exudate and quorum sensing molecules. Brazilian Journal of Microbiology, 44 (4): 1331-1339 http://dx.doi.org/10.1590/S1517-83822013000400044

Elbeltagy A., Nishioka K., Sato T., Suzuki H., Ye B., Hamada T., Isawa T., Mitsui H., Minamisawa K. 2001. Endophytic colonization and in planta nitrogen fixation by a Herbaspirillum sp. isolated from wild rice species. Applied and Environmental Microbiology, 67 (11): 5285-5293 http://dx.doi.org/10.1128/AEM.67.11.5285-5293.2001

Engelhard M., Hurek T., Reinhold-Hurek B. 2000. Preferential occurrence of diazotrophic endophytes, Azoarcus spp., in wild rice species and land races of Oryza sativa in comparison with modern races. Environmental Microbiology, 2 (2): 131-141 http://dx.doi.org/10.1046/j.1462-2920.2000.00078.x

Fernandez O., Theocharis A., Bordiec S., Feil R., Jacquens L., Clement C., Fontaine F., Barka E. A. 2012. Burkholderia phytofirmans PsJN acclimates grapevine to cold by modulating carbohydrate metabolism. Molecular PlantMicrobe Interactions Journal, 25 (4): 496-504 http://dx.doi.org/10.1094/MPMI-09-11-0245

Fisher P. J., Petrini O., Scott H. M. L. 1992. The distribution of some fungal and bacterial endophytes in maize (Zea mays L.). New Phytologist, 122: 299-305 http://dx.doi.org/10.1111/j.1469-8137.1992.tb04234.x

Foley J. A., Defries R., Asner G. P., Barford C., Bonan G., Carpenter S. R., Chapin F. S., Coe M. T., Daily G. C., Gibbs H. K., Helkowski J. H., Holloway T., Howard E. A., Kucharik C. J., Monfreda C., Patz J. A., Prentice I. C., Ramankutty N., Snyder P. K. 2005. Global consequences of land use. Science, 309 (5734): 570-574 http://dx.doi.org/10.1126/science. 1111772

Fuentes-Ramirez L. E., Caballero-Mellado J., Sepulveda J., Martinez-Romero E. 1999. Colonization of sugarcane by Acetobacter diazotrophicus is inhibited by high N-fertilization. FEMS Microbiology Ecology, 29 (2): 117-128 http://dx.doi.org/10.1016/S0168-6496(98)00125-1

Gagne S., Richard H., Rousseau H., Antoun H. 1987. Xylemresiding bacteria in alfalfa roots. Canadian Journal of Microbiology, 33: 996-1000 http://dx.doi.org/10.1139/m87-175
Garcia de Salamone I. E., Hynes R. K., Nelson L. M. 2001. Cytokinin production by plant growth promoting rhizobacteria and selected mutants. Canadian Journal of Microbiology, 47 (5): 404-411 http://dx.doi.org/10.1139/w01-029

Garcia-Orenes F., Morugan-Coronado A., Zornoza R., Scow K. 2013. Changes in soil microbial community structure influenced by agricultural management practices in a mediterranean agro-ecosystem. PLoS ONE, 8 (11): e80522 http://dx.doi.org/10.1371/journal.pone.0080522

Glick B. R. 2012. Plant growth-promoting bacteria: mechanisms and applications. Scientifica, 2012: 1-15 http://dx.doi.org/10.6064/2012/963401

Glick B. R. 2014. Bacteria with ACC deaminase can promote plant growth and help to feed the world. Microbiological Research, 169 (1): 30-39 http://dx.doi.org/10.1016/j.micres.2013.09.009

Govindasamy V., Franco C. M. M., Gupta V. V. S. R. 2014. Endophytic actinobacteria: diversity and ecology. Advances in endophytic research, p. 27-59

Gupta C., Dubey R., Maheshwari D. 2002. Plant growth enhancement and suppression of Macrophomina phaseolina causing charcoal rot of peanut by fluorescent Pseudomonas. Biology and Fertility of Soils, 35: 399-405 http://dx.doi.org/10.1007/s00374-002-0486-0

Haas D., Defago G. 2005. Biological control of soil-borne pathogens by fluorescent pseudomonads. Nature Reviews Microbiology, 3 (4): 307-319 http://dx.doi.org/10.1038/nrmicro1129

Hallman J., Quadt-Hallman A., Mahafee W. F., Kloepper J. W. 1997. Bacterial endophytes in agricultural crops. Canadian Journal of Microbiology, 43: 895-914 http://dx.doi.org/10.1139/m97-131

Hallman J., Rodriguez-Kabana R., Kloepper J. W. 1999. Chitin-mediated changes in bacterial communities of the soil, rhizosphere and within roots of cotton in relation to nematode control. Soil Biology and Biochemistry, 31: $551-560$ http://dx.doi.org/10.1016/S0038-0717(98)00146-1

Hamilton C. E., Gundel P. E., Helander M., Saikkonen K. 2012. Endophytic mediation of reactive oxygen species and antioxidant activity in plants: a review. Fungal Diversity, 54 (1): $1-10$ http://dx.doi.org/10.1007/s13225-012-0158-9

Handelsman J. 2004. Metagenomics: application of genomics to uncultured microorganisms. Microbiology and Molecular Biology Reviews, 68 (4): 669-685 http://dx.doi.org/10.1128/MMBR.68.4.669-685.2004

Hardoim P. R., van Overbeek L. S., Elsas J. D. 2008. Properties of bacterial endophytes and their proposed role in plant growth. Trends in Microbiology, 16 (10): 463-471 http://dx.doi.org/10.1016/j.tim.2008.07.008

Hartmann A., Rothballer M., Hense B. A., Schroder P. 2014. Bacterial quorum sensing compounds are important modulators of microbe-plant interactions. Frontiers in Plant Science, 5: 131 http://dx.doi.org/10.3389/fpls.2014.00131

Heffer P. 2013. Assessment of fertilizer use by crop at the global level 2010-2010/11, p. 1-9

Hoffman M. T., Gunatilaka M. K., Wijeratne K., Gunatilaka L., Arnold A. E. 2013. Endohyphal bacterium enhances production of indole-3-acetic acid by a foliar fungal endophyte. PLoS ONE, 8 (9): e73132 http://dx.doi.org/10.1371/journal.pone.0073132 
Holden N., Pritchard L., Toth I. 2009. Colonization outwith the colon: plants as an alternative environmental reservoir for human pathogenic enterobacteria. FEMS Microbiology Reviews, 33 (4): 689-703 http://dx.doi.org/10.1111/j.1574-6976.2008.00153.x

Hollis J. P. 1951. Bacteria in healthy potato tissue. Phytopathology Journal, 41: 350-367

Hosni T., Moretti C., Devescovi G., Suarez-Moreno Z. R., Fatmi M. B., Guarnaccia C., Pongor S., Onofri A., Buonaurio R., Venturi V. 2011. Sharing of quorum-sensing signals and role of interspecies communities in a bacterial plant disease. The ISME Journal, 5 (12): 1857-1870 http://dx.doi.org/10.1038/ismej.2011.65

Ikeda S., Kaneko T., Okubo T., Rallos L. E., Eda S., Mitsui H., Sato S., Nakamura Y., Tabata S., Minamisawa K. 2009. Development of a bacterial cell enrichment method and its application to the community analysis in soybean stems. Microbial Ecology, 58 (4): 703-714

http://dx.doi.org/10.1007/s00248-009-9566-0

Iniguez A. L., Dong Y., Triplett E. W. 2004. Nitrogen fixation in wheat provided by Klebsiella pneumoniae 342. Molecular Plant-Microbe Interactions Journal, 17 (10): 1078-1085 http://dx.doi.org/10.1094/MPMI.2004.17.10.1078

Jacobs M. J., Bugbee W. M., Gabrielson D. A. 1985. Enumeration, location, and characterization of endophytic bacteria within sugar beet roots. Canadian Journal of Botany, 63: 1262-1265 http://dx.doi.org/10.1139/b85-174

Jangid K., Williams M. A., Franzluebbers A. J., Sanderlin J. S., Reeves J. H., Jenkins M. B., Endale D. M., Coleman D. C., Whitman W. B. 2008. Relative impacts of land-use, management intensity and fertilization upon soil microbial community structure in agricultural systems. Soil Biology and Biochemistry, 40 (11): 2843-2853

http://dx.doi.org/10.1016/j.soilbio.2008.07.030

Jha P. N., Gupta G., Jha P., Mehrotra R. 2013. Association of rhizospheric/endophytic bacteria with plants: a potential gateway to sustainable agriculture. Greener Journal of Agricultural Sciences, 3 (2): 73-84

Jha Y., Subramanian R. B., Patel S. 2011. Combination of endophytic and rhizospheric plant growth promoting rhizobacteria in Oryza sativa shows higher accumulation of osmoprotectant against saline stress. Acta Physiologiae Plantarum, 33: 797-802

http://dx.doi.org/10.1007/s11738-010-0604-9

Jiao J. Y., Wang H. X., Zeng Y., Shen Y. M. 2006. Enrichment for microbes living in association with plant tissues. Journal of Applied Microbiology, 100 (4): 830-837 http://dx.doi.org/10.1111/j.1365-2672.2006.02830.x

Karthikeyan B., Joe M. M., Islam R., Sa T. 2012. ACC deaminase containing diazotrophic endophytic bacteria ameliorate salt stress in Catharanthus roseus through reduced ethylene levels and induction of antioxidative defense systems. Symbiosis, 56 (2): 77-86 http://dx.doi.org/10.1007/s13199-012-0162-6

Kinkel L. L., Schlatter D. C., Bakker M. G., Arenz B. E. 2012. Streptomyces competition and co-evolution in relation to plant disease suppression. Research in Microbiology, 163 (8): 490-499 http://dx.doi.org/10.1016/j.resmic.2012.07.005

Kloepper J. W., Ryu C.-M. 2006. Bacterial endophytes as elicitors of induced systemic resistance. Microbial root endophytes, p. 33-52

http://dx.doi.org/10.1007/3-540-33526-9_3
Kobayashi D. Y., Palumbo J. D. 2000. Bacterial endophytes and their effects on plants and uses in agriculture. Microbial endophytes, p. 199-233

Kuklinsky-Sobral K., Araujo W. L., Mendonca C., Geran L. C., Piskala A., Azevedo J. L. 2004. Isolation and characterization of soybean-associated bacteria and their potential for plant growth promotion. Environmental Microbiology, 6: 1244-1251 http://dx.doi.org/10.1111/j.1462-2920.2004.00658.x

Kusari P., Kusari S., Lamshoft M., Sezgin S., Spiteller M., Kayser O. 2014. Quorum quenching is an antivirulence strategy employed by endophytic bacteria. Applied Microbiology and Biotechnology, 98 (16): 7173-7183 http://dx.doi.org/10.1007/s00253-014-5807-3

Kutter S., Hartmann A., Schmid M. 2006. Colonization of barley (Hordeum vulgare) with Salmonella enterica and Listeria spp. FEMS Microbiology Ecology, 56 (2): 262-271 http://dx.doi.org/10.1111/j.1574-6941.2005.00053.x

Lackner G., Moebius N., Hertweck C. 2011. Endofungal bacterium controls its host by an hrp type III secretion system. The ISME Journal, 5 (2): 252-261 http://dx.doi.org/10.1038/ismej.2010.126

Lalande R. N., Bissonnette N., Coutlee D., Antoun H. 1989. Identification of rhizobacteria from maize and determination of their plant-growth promoting potential. Plant and Soil, 115: 7-11 http://dx.doi.org/10.1007/BF02220688

Latz E., Eisenhauer N., Rall B. C., Allan E., Roscher C., Scheu S., Jousset A. 2012. Plant diversity improves protection against soil-borne pathogens by fostering antagonistic bacterial communities. Journal of Ecology, 100 (3): 597-604 http://dx.doi.org/10.1111/j.1365-2745.2011.01940.x

Lodewyckx C., Mergeay M., Vangronsveld J., Clijsters H., Van der Lelie D. 2002. Isolation, characterization, and identification of bacteria associated with the zinc hyperaccumulator Thlaspicaerulescens subsp.calaminaria. International Journal of Phytoremediation, 4 (2): 101-115 http://dx.doi.org/10.1080/15226510208500076

Lorang J. M., Anderson N. A., Lauer F. I., Wildung D. K. 1989. Disease decline in a Minnesota potato scab plot. American Potato Journal, 66: 531

Ma Y., Rajkumar M., Freitas H. 2009. Inoculation of plant growth promoting bacterium Achromobacter xylosoxidans strain Ax10 for the improvement of copper phytoextraction by Brassica juncea. Journal of Environmental Management, 90 (2): 831-837 http://dx.doi.org/10.1016/j.jenvman.2008.01.014

Manter D. K., Delgado J. A., Holm D. G., Stong R. A. 2010. Pyrosequencing reveals a highly diverse and cultivarspecific bacterial endophyte community in potato roots. Microbial Ecology, 60 (1): 157-166 http://dx.doi.org/10.1007/s00248-010-9658-x

Maropola M. K., Ramond J. B., Trindade M. 2015. Impact of metagenomic DNA extraction procedures on the identifiable endophytic bacterial diversity in Sorghum bicolor (L. Moench). Journal of Microbiological Methods, 112: 104-117 http://dx.doi.org/10.1016/j.mimet.2015.03.012

Mavingui P., Laguerre G., Berge O., Heulin T. 1992. Genetic and phenotypic diversity of Bacillus polymyxa in soil and in the wheat rhizosphere. Applied and Environmental Microbiology, 58 (6): 1894-1903

Mbai F. N., Magiri E. N., Matiru V. N., Nganga J., Nyambati V. C. S. 2015. Isolation and characterization of bacterial root endophytes with potential to enhance plant growth from Kenyan Basmati rice. American International Journal of Contemporary Research, 3 (4): 25-40 
McInroy J. A., Kloepper J. W. 1995. Population dynamics of endophytic bacteria in field-grown sweet corn and cotton. Canadian Journal of Microbiology, 41: 895-901 http://dx.doi.org/10.1139/m95-123

Mei C., Flinn B. S. 2010. The use of beneficial microbial endophytes for plant biomass and stress tolerance improvement. Recent Patents on Biotechnology, 4 (1): 81-95 http://dx.doi.org/10.2174/187220810790069523

Mendes R., Kruijt M., de Bruijn I, Dekkers E., van der Voort M., Schneider J. H., Piceno Y. M., DeSantis T. Z., Andersen G. L., Bakker P. A., Raaijmakers J. M. 2011. Deciphering the rhizosphere microbiome for diseasesuppressive bacteria. Science, 332 (6033): 1097-1100 http://dx.doi.org/10.1126/science.1203980

Mirza M. S., Ahmad W., LatifF., Haurat J., Bally R., Normand P., Malik K. A. 2001. Isolation, partial characterization, and the effect of plant growth-promoting bacteria (PGPB) on micro-propagated sugarcane in vitro. Plant and Soil, 237 (1): 47-54 http://dx.doi.org/10.1023/A:1013388619231

Misaghi I. J., Donndelinger C. R. 1990. Endophytic bacteria in symptom-free cotton plants. Phytopathology Journal, 80: $808-811$ http://dx.doi.org/10.1094/Phyto-80-808

Mundt J. O., Hinkle N. F. 1976. Bacteria within ovules and seeds. Applied and Environmental Microbiology, 32 (5): 694-698

Naveed M., Hussain M. B., Zahir Z. A., Mitter B., Sessitsch A. 2014. Drought stress amelioration in wheat through inoculation with Burkholderia phytofirmans strain PsJN. Plant Growth Regulation, 73: 121-131

http://dx.doi.org/10.1007/s10725-013-9874-8

Naveed M., Qureshi M. A., Zahir Z. A., Hussain M. B., Sessitsch A., Mitter B. 2015. L-Tryptophan-dependent biosynthesis of indole-3-acetic acid (IAA) improves plant growth and colonization of maize by Burkholderia phytofirmans PsJN. Annals of Microbiology, 65: 1391-1389 http://dx.doi.org/10.1007/s13213-014-0976-y

Nikolic B., Schwab H., Sessitsch A. 2011. Metagenomic analysis of the 1-aminocyclopropane-1-carboxylate deaminase gene (acdS) operon of an uncultured bacterial endophyte colonizing Solanum tuberosum L. Archives of Microbiology, 193 (9): 665-676 http://dx.doi.org/10.1007/s00203-011-0703-z

Palus J. A., Borneman J., Ludden P. W., Triplett E. W. 1996. A diazotrophic bacterial endophyte isolated from stems of Zea mays L. and Zea luxurians Iltis and Doebley. Plant and Soil, 186: 135-142 http://dx.doi.org/10.1007/BF00035067

Pampulha M. E., Oliveira A. 2006. Impact of an herbicide combination of bromoxynil and prosulfuron on soil microorganisms. Current Microbiology, 53 (3): 238-243 http://dx.doi.org/10.1007/s00284-006-0116-4

Patel H. A., Patel R. K., Khristi S. M., Parikh K., Rajendran G. 2012. Isolation and characterization of bacterial endophytes from Lycopersicon esculentum plant and their plant growth promoting characteristics. Nepal Journal of Biotechnology, 2 (1): $37-52$ http://dx.doi.org/10.3126/njb.v2i1.5679

Philippot L., Raaijmakers J. M., Lemanceau P., van der Putten W. H. 2013. Going back to the roots: the microbial ecology of the rhizosphere. Nature Reviews Microbiology, 11 (11): 789-799 http://dx.doi.org/10.1038/nrmicro3109
Pieterse C. M., Van der Does D., Zamioudis C., Leon-Reyes A., Van Wees S. C. 2012. Hormonal modulation of plant immunity. Annual Review of Cell and Developmental Biology, 28: 489-521

http://dx.doi.org/10.1146/annurev-cellbio-092910-154055

Pieterse C. M., Zamioudis C., Berendsen R. L., Weller D. M., Van Wees S. C., Bakker P. A. 2014. Induced systemic resistance by beneficial microbes. Annual Review of Phytopathology, 52: 347-375

http://dx.doi.org/10.1146/annurev-phyto-082712-102340

Pillay V. K., Nowak J. 1997. Inoculum density, temperature, and genotype effects on in vitro growth promotion and epiphytic and endophytic colonization of tomato (Lysopersicon esculentum L.) seedlings inoculated with a pseudomonad bacterium. Canadian Journal of Microbiology, 43: 354-361 http://dx.doi.org/10.1139/m97-049

Pozo M. J., Van Der Ent S., Van Loon L. C., Pieterse C. M. 2008. Transcription factor MYC2 is involved in priming for enhanced defense during rhizobacteria-induced systemic resistance in Arabidopsis thaliana. New Phytologist, 180 (2): 511-523 http://dx.doi.org/10.1111/j.1469-8137.2008.02578.x

Qin S., Zhang Y.-J., Yuan B., Xu P.-Y., Xing K., Wang J., Jiang J.-H. 2014. Isolation of ACC deaminase-producing habitat-adapted symbiotic bacteria associated with halophyte Limonium sinense (Girard) Kuntze and evaluating their plant growth-promoting activity under salt stress. Plant and Soil, 374: 753-766 http://dx.doi.org/10.1007/s11104-013-1918-3

Raaijmakers J. M., Mazzola M. 2012. Diversity and natural functions of antibiotics produced by beneficial and plant pathogenic bacteria. Annual Review of Phytopathology, 50: $403-424$

http://dx.doi.org/10.1146/annurev-phyto-081211-172908

Rai R., Dash P. K., Prasanna B. M., Singh A. 2007. Endophytic bacterial flora in the stem tissue of a tropical maize (Zea mays L.) genotype: isolation, identification and enumeration. World Journal of Microbiology and Biotechnology, 23: 853-858 http://dx.doi.org/10.1007/s11274-006-9309-z

Rajesh P. S., Ravishankar R. V. 2014. Quorum quenching activity in cell-free lysate of endophytic bacteria isolated from Pterocarpus santalinus Linn., and its effect on quorum sensing regulated biofilm in Pseudomonas aeruginosa PAO1. Microbiological Research, 169 (7-8): 561-569 http://dx.doi.org/10.1016/j.micres.2013.10.005

Reinhold-Hurek B., Hurek T. 2011. Living inside plants: bacterial endophytes. Current Opinion in Plant Biology, 14 (4): 435-443 http://dx.doi.org/10.1016/j.pbi.2011.04.004

Reiter B., Pfeifer U., Schwab H., Sessitsch A. 2002. Response of endophytic bacterial communities in potato plants to infection with Erwinia carotovora subsp. atroseptica. Applied and Environmental Microbiology, 68 (5): 2261-2268 http://dx.doi.org/10.1128/AEM.68.5.2261-2268.2002

Rosenblueth M., Martinez-Romero E. 2004. Rhizobium etli maize populations and their competitiveness for root colonization. Archives of Microbiology, 181 (5): 337-344 http://dx.doi.org/10.1007/s00203-004-0661-9

Rosenblueth M., Martinez-Romero E. 2006. Bacterial endophytes and their interactions with hosts. Molecular Plant-Microbe Interactions Journal, 19 (8): 827-837 http:/dx.doi.org/10.1094/MPMI-19-0827 
Ryan R. P., Germaine K., Franks A., Ryan D. J., Dowling D. N. 2008. Bacterial endophytes: recent developments and applications. FEMS Microbiology Letters, 278 (1): 1-9 http://dx.doi.org/10.1111/j.1574-6968.2007.00918.x

Samish Z., Etinger-Tulczynska R., Bick M. 1961. Microflora within healthy tomatoes. Applied Microbiology, 9: 20-25

Sandhiya G. S., Sugitha T. C., Balachandar D., Kumar K. 2005. Endophytic colonization and in planta nitrogen fixation by diazotrophic Serratia sp. in rice. Indian Journal of Experimental Biology, 43: 802-807

Schaefer A. L., Lappala C. R., Morlen R. P., Pelletier D. A., Lu T. Y., Lankford P. K., Harwood C. S., Greenberg E. P. 2013. LuxR- and luxI-type quorum-sensing circuits are prevalent in members of the Populus deltoides microbiome. Applied and Environmental Microbiology, 79 (18): 5745-5752 http://dx.doi.org/10.1128/AEM.01417-13

Scher F. M., Baker R. 1980. Mechanism of biological control in a Fusarium-suppressive soil. Phytopathology Journal, 70: 412-417 http://dx.doi.org/10.1094/Phyto-70-412

Schikora A., Carreri A., Charpentier E., Hirt H. 2008. The dark side of the salad: Salmonella typhimurium overcomes the innate immune response of Arabidopsis thaliana and shows an endopathogenic lifestyle. PLoS ONE, 3 (5): e2279 http://dx.doi.org/10.1371/journal.pone.0002279

Schulz B., Boyle C. 2006. What are endophytes? Microbial root endophytes, p. 1-13 http://dx.doi.org/10.1007/3-540-33526-9_1

Seghers D., Wittebolle L., Top E. M., Verstraete W., Siciliano S. D. 2004. Impact of agricultural practices on the Zea mays L. endophytic community. Applied and Environmental Microbiology, 70 (3): 1475-1482 http://dx.doi.org/10.1128/AEM.70.3.1475-1482.2004

Seo W. T., Lim W. J., Kim E. J., Yun H. D., Lee Y. H., Cho K. M. 2010. Endophytic bacterial diversity in the youngradish and their antimicrobial activity against pathogens. Journal of the Korean Society for Applied Biological Chemistry, 53: 493-503 http://dx.doi.org/10.3839/jksabc.2010.075

Sessitsch A., Hardoim P., Doring J., Weilharter A., Krause A., Woyke T., Mitter B., Hauberg-Lotte L., Friedrich F., Rahalkar M., Hurek T., Sarkar A., Bodrossy L., van Overbeek L., Brar D., van Elsas J. D., Reinhold-Hurek B. 2012. Functional characteristics of an endophyte community colonizing rice roots as revealed by metagenomic analysis. Molecular Plant-Microbe Interactions Journal, 25 (1): $28-36$ http://dx.doi.org/10.1094/MPMI-08-11-0204

Siddiqui I. A., Ehteshamul-Haque S. 2001. Suppression of the root rot-root knot disease complex by Pseudomonas aeruginosa in tomato: the influence of inoculum density, nematode populations, moisture and other plant-associated bacteria. Plant and Soil, 237: 81-89 http://dx.doi.org/10.1023/A:1013313103032

Singh J. S., Pandey V. C., Singh D. P. 2011. Efficient soil microorganisms: a new dimension for sustainable agriculture and environmental development. Agriculture, Ecosystems and Environment, 140 (3-4): 339-353 http://dx.doi.org/10.1016/j.agee.2011.01.017

Smith K. P., Goodman R. M. 1999. Host variation for interactions with beneficial plant-associated microbes. Annual Review of Phytopathology, 37: 473-491

http://dx.doi.org/10.1146/annurev.phyto.37.1.473
Soupir M. L., Mostaghimi S., Yagow E. R., Hagedorn C., Vaughan D. H. 2006. Transport of fecal bacteria from poultry litter and cattle manures applied to pastureland. Water Air Soil and Pollution, 169 (1-4): 125-136 http://dx.doi.org/10.1007/s11270-006-1808-x

Souza S. A., Xavier A. A., Costa M. R., Cardoso A. M., Pereira M. C., Nietsche S. 2013. Endophytic bacterial diversity in banana 'Prata Ana' (Musa spp.) roots. Genetics and Molecular Biology, 36 (2): 252-264 http://dx.doi.org/10.1590/S1415-47572013000200016

Spoel S. H., Koornneef A., Claessens S. M., Korzelius J. P., Van Pelt J. A., Mueller M. J., Buchala A. J., Metraux J. P., Brown R., Kazan K., Van Loon L. C., Dong X., Pieterse C. M. 2003. NPR1 modulates cross-talk between salicylate- and jasmonate-dependent defense pathways through a novel function in the cytosol. The Plant Cell, 15 (3): 760-770 http://dx.doi.org/10.1105/tpc.009159

Stajkovic O., De Meyer S., Milicic B., Willems A., Delic D. 2009. Isolation and characterization of endophytic nonrhizobial bacteria from root nodules of alfalfa (Medicago sativa L.). Botanica Serbica, 33 (1): 107-114

Stein E., Molitor A., Kogel K. H., Waller F. 2008. Systemic resistance in Arabidopsis conferred by the mycorrhizal fungus Piriformospora indica requires jasmonic acid signaling and the cytoplasmic function of NPR1. Plant and Cell Physiology, 49 (11): 1747-1751 http://dx.doi.org/10.1093/pcp/pcn147

Stolzfus J. R., So R. M. P. P., Ladha J. K., de Bruijn F. J. 1997. Isolation of endophytic bacteria from rice and assessment of their potential for supplying rice with biologically fixed nitrogen. Plant and Soil, 194: 25-36 http://dx.doi.org/10.1023/A:1004298921641

Sturz A. V., Chriestie B. R., Matheson B. G. 1998. Association of bacterial endophyte populations from red clover and potato crops with potential for beneficial allelopathy. Canadian Journal of Microbiology, 44: 162-167 http://dx.doi.org/10.1139/w97-146

Sturz A. V., Christie B. R., Nowak J. 2000. Bacterial endophytes: potential role in developing sustainable systems of crop production. Critical Reviews in Plant Sciences, 19: 1-30 http://dx.doi.org/10.1016/S0735-2689(01)80001-0

Sun L., Qiu F., Zhang X., Dai X., Dong X., Song W. 2008. Endophytic bacterial diversity in rice (Oryza sativa L.) roots estimated by $16 \mathrm{~S}$ rDNA sequence analysis. Microbial Ecology, 55 (3): 415-424 http://dx.doi.org/10.1007/s00248-007-9287-1

Surette M. A., Sturz A. V., Lada R. R., Nowak J. 2003. Bacterial endophytes in processing carrots (Daucus carota L. var. sativus): their localization, population density, biodiversity and their effects on plant growth. Plant and Soil, 253: 381-390 http://dx.doi.org/10.1023/A:1024835208421

Theocharis A., Bordiec S., Fernandez O., Paquis S., DhondtCordelier S., Baillieul F., Clement C., Barka E. A. 2012. Burkholderia phytofirmans PsJN primes Vitis vinifera L. and confers a better tolerance to low nonfreezing temperatures. Molecular Plant-Microbe Interactions Journal, 25 (2): 241-249 http://dx.doi.org/10.1094/MPMI-05-11-0124

Trognitz F., Piller K., Nagel M., Borner A., Bacher C.-F., Rechlik M., Mayrhofer H., Sessitsch A. 2014. Isolation and characterization of endophytes isolated from seeds of different plants and the application to increase juvenile development. Tagung der Vereinigung der Pflanzenzüchter und Saatgutkaufleute Osterreichs, 65: 25-28 
Tsurumaru H., Okubo T., Okazaki K., Hashimoto M., Kakizaki K., Hanzawa E., Takahashi H., Asanome N., Tanaka F., Sekiyama Y., Ikeda S., Minamisawa K. 2015. Metagenomic analysis of the bacterial community associated with the taproot of sugar beet. Microbes and Environments, 30 (1): 63-69 http://dx.doi.org/10.1264/jsme2.ME14109

Tuteja N. 2007. Abscisic acid and abiotic stress signaling. Plant Signaling and Behavior, 2 (3): 135-138 http://dx.doi.org/10.4161/psb.2.3.4156

Van Der Ent S., Verhagen B. W., Van Doorn R., Bakker D., Verlaan M. G., Pel M. J., Joosten R. G., Proveniers M. C., Van Loon L. C., Ton J., Pieterse C. M. 2008. MYB72 is required in early signaling steps of rhizobacteria-induced systemic resistance in Arabidopsis. Plant Physiology, 146 (3): 1293-1304 http://dx.doi.org/10.1104/pp.107.113829

Wang M., Xing Y., Wang J., Xu Y., Wang G. 2014. The role of the chil gene from the endophytic bacteria Serratia proteamaculans $336 \mathrm{x}$ in the biological control of wheat takeall. Canadian Journal of Microbiology, 60 (8): 533-540 http://dx.doi.org/10.1139/cjm-2014-0212

Wei G., Kloepper J. W., Tuzan S. 1991. Induction of systemic resistance of cucumber to Colletotrichum orbiculare by select strains of plant growth-promoting rhizobacteria. Phytopathology Journal, 81: 1508-1512 http://dx.doi.org/10.1094/Phyto-81-1508

Weller D. M., Raaijmakers J. M., Gardener B. B., Thomashow L. S. 2002. Microbial populations responsible for specific soil suppressiveness to plant pathogens. Annual Review of Phytopathology, 40: 309-348 http://dx.doi.org/10.1146/annurev.phyto.40.030402.110010

West E. R., Cother E. J., Steel C. C., Ash G. J. 2010. The characterization and diversity of bacterial endophytes of grapevine. Canadian Journal of Microbiology, 56: 209 216 http://dx.doi.org/10.1139/W10-004

Whipps J. M. 1997. Developments in the biological control of soil-borne plant pathogens. Advances in Botanical Research, 26: 1-134 http://dx.doi.org/10.1016/S0065-2296(08)60119-6

Yang C. J., Zhang X. G., Shi G. Y., Zhao H. Y., Chen L., Tao K., Hou T. P. 2011. Isolation and Identification of endophytic bacterium W4 against tomato Botrytis cinerea and antagonistic activity stability. African Journal of Microbiology Research, 5: 131-136

Yanni Y. G., Rizk R. Y., Corich V., Squartini A., Ninke K., PhilipHollingsworth S., Orgambide G., de Bruijn F., Stoltzfus J., Buckley D., Schmidt T. M., Mateos P. F., Ladha J. K., Dazzo F. B. 1997. Natural endophytic association between Rhizobium leguminosarum cv. trifolii and rice roots and assessment of its potential to promote rice growth. Plant and Soil, 194: 99-114

http://dx.doi.org/10.1023/A:1004269902246

You C., Zhou F. 1989. Non-nodular endorhizospheric nitrogen fixation in wetland rice. Canadian Journal of Microbiology, 35: 403-408 http://dx.doi.org/10.1139/m89-062

Zhang Y. F., He L. Y., Chen Z. J., Wang Q. Y., Qian M., Sheng X. F. 2011 (a). Characterization of ACC deaminaseproducing endophytic bacteria isolated from coppertolerant plants and their potential in promoting the growth and copper accumulation of Brassica napus. Chemosphere, 83 (1): 57-62

http://dx.doi.org/10.1016/j.chemosphere.2011.01.041
Zhang Y. F., He L. Y., Chen Z. J., Zhang W.-H., Wang Q. Y., Qian M., Sheng X. F. 2011 (b). Characterization of leadresistant and ACC deaminase-producing endophytic bacteria and their potential in promoting lead accumulation of rape. Journal of Hazardous Materials, 186 (2-3): 1720-1725 http://dx.doi.org/10.1016/j.jhazmat.2010.12.069

Zhong W., Gu T., Wang W., Zhang B., Lin X., Huang Q., Shen W. 2010. The effects of mineral fertilizer and organic manure on soil microbial community and diversity. Plant and Soil, 326 (1-2): 511-522 http://dx.doi.org/10.1007/s11104-009-9988-y

Zinniel D. K., Lambrecht P., Harris N. B., Feng Z., Kuczmarski D., Higley P., Ishimaru C. A., Arunakumari A., Barletta R. G., Vidaver A. K. 2002. Isolation and characterization of endophytic colonizing bacteria from agronomic crops and prairie plants. Applied and Environmental Microbiology, 68 (5): 2198-2208 http://dx.doi.org/10.1128/AEM.68.5.2198-2208.2002 
ISSN 1392-3196 / e-ISSN 2335-8947

Zemdirbyste-Agriculture, vol. 102, No. 4 (2015), p. 465-478

DOI 10.13080/z-a.2015.102.060

\title{
Bakterinių endofitų reikšmė žemès ūkio augalų atsparumui stresui: apžvalga
}

\author{
I. Miliūté ${ }^{1}$, O. Buzaitè ${ }^{1}$, D. Baniulis ${ }^{1}$, V. Stanys ${ }^{1,2}$
}

${ }^{1}$ Lietuvos agrarinių ir miškų mokslų centro Sodininkystès ir daržininkystès institutas

${ }^{2}$ Aleksandro Stulginskio universitetas

\section{Santrauka}

Bakteriniai endofitai yra augaluose plačiai paplitusi endosimbiontinių mikroorganizmų grupė, kuri kolonizuoja visų augalo dalių tarpląstelines bei viduląstelines sritis ir nesukelia augalų ligų ar reikšmingų morfologinių pakitimų. Augalų ir endofitinių bakterijų sąveikai būdinga didelè taksonominè bakterijų ir augalų įvairovè. Apžvalgoje apibendrintos žinios apie ištirtų būdingų žemès ūkio augalų endofitų taksonominè sudètị. Pastaraji dešimtmetị naujų duomenų apie šių mikroorganizmų ịvairovę pateikè naujų metagenominès analizès metodų taikymas tiriant endofitines bakterijas. Endofitinių bakterijų bendrijų struktūrą lemia augalo genotipas, aplinkos sąlygos, mikroorganizmų tarpusavio sąveika ir jų sąveika su augalais. Tokios žemės dirbimo technologijos kaip dirvos arimas, drèkinimas, pesticidų ir trąšų naudojimas turi didelę įtaką dirvožemio bei endofitinių mikroorganizmų populiacijų funkcijoms ir struktūrai. Todèl natūralią augalų endofitinių bakterijų ịvairovę palaikančios žemès ūkio technologijos tampa svarbia darnios žemdirbystės dalimi, užtikrinančia dideli augalų produktyvumą ir žemès ūkio produkcijos kokybę. Iৃvairios endofitinių mikroorganizmų bendrijos yra neatsiejama agroekosistemų dalis, svarbi jų funkcionavimui. Nustatyta, kad endofitinès bakterijos gali skatinti augalo šeimininko augimą, reguliuoti metabolizmą, fitohormonų signalinius kelius ir tokiu būdu didinti augalų atsparumą aplinkos abiotiniam ar biotiniam stresui. Endofitinių bakterijų panaudojimas sudaro galimybę kurti žemès ūkio technologijas, kurios užtikrintų didesnị augalų atsparumą šalčio, sausros ar užterštų dirvožemių stresui arba padidintų augalų atsparumą ligoms.

Reikšminiai žodžiai: augalų adaptyvumas, endofitinė mikrobioma, mikroorganizmų bendrijos, mikroorganizmų ivvairovè, žemès ūkio technologijos. 